\title{
IMPLEMENTASI MODEL PEMBELAJARAN SIMPOSIUM UNTUK MENINGKATKAN PEMAHAMAN DAN HASIL BELAJAR KOGNITIF MAHASISWA PADA MATERI FAKTOR BIOTIK DAN PRINSIP EKOLOGI
}

\author{
Aldila Wanda Nugraha ${ }^{1}$ \\ ${ }^{1}$ Prodi Pendidikan IPA, Universitas Bhinneka PGRI \\ email: aldilanugraha89@gmail.com
}

\begin{abstract}
ABSTRAK
Penelitian ini merupakan penelitian kualitatif menggunakan penelitian tindakan kelas (PTK) yang digunakan untuk memperoleh informasi dan gambaran tentang aktifitas dan hasil belajar mahasiswa selama proses pembelajaran. Penelitian ini bertujuan untuk meningkatkan praktek pembelajaran di kelas yakni dengan menerapkan Active Learning dengan tujuan dapat meningkatkan pemahaman belajar dan hasil belajar kognitif mahasiswa pada matakuliah Pendidikan Sains di STKIP PGRI Tulungagung. Berdasarkan Penelitian Tindakan Kelas yang telah dilakukan diperoleh kesimpulan bahwa Pembelajaran aktif dengan implementasi model pembelajaran simposium dapat meningkatkan pemahaman dan hasil belajar kognitif mahasiswa pada matakuliah pendidikan sains. Hal ini dibuktikan dengan hasil tes tiap akhir siklus yang mengalami peningkatan. Pada siklus 1 tindakan, rata-rata nilai tes mahasiswa adalah 79.4 dan pada siklus 2 tindakan meningkat menjadi 81.5.
\end{abstract}

Kata Kunci: Active learning, kognitif, simposium

\section{ABSTRACT}

This research is a qualitative study using classroom action research (CAR) used to obtain information and an overview of student learning activities and outcomes during the learning process. This study aims to improve learning practices in the classroom by implementing Active Learning with the aim of improving students' understanding of learning and cognitive learning outcomes in the Science Education course at STKIP PGRI Tulungagung. Based on the Classroom Action Research that has been conducted, it can be concluded that active learning with the implementation of the symposium learning model can improve students' understanding and cognitive learning outcomes in science education courses. This is evidenced by the results of tests at the end of each cycle that has increased. In cycle 1, the average test score of students is 79.4 and in cycle 2 the action increases to 81.5.

Keywords: Active learning, cognitive, symposium 


\section{PENDAHULUAN}

Untuk dapat meningkatkan kualitas pembelajaran, para Dosen harus memiliki ketrampilan memilih dan menggunakan metode ajar dan model belajar untuk diterapkan dalam sistem pembelajaran yang efektif (Hamalik, 2001). Salah satu pendekatan pembelajaran yang dapat membuat mahasiswa lebih aktif adalah pembelajaran dengan Active learning.

Active Learning atau pembelajaran aktif adalah suatu proses pembelajaran yang memberikan kesempatan kepada siswa untuk berperan lebih aktif dalam proses pembelajaran (menemukan ide pokok dari materi pelajaran, memecahkan persoalan, atau mengaplikasikan apa yang baru mereka pelajari ke dalam satu persoalan yang ada dalam kehidupan nyata), dengan menyediakan lingkungan belajar yang membuat siswa tidak tertekan dan senang melaksanakan kegiatan belajar.

Hasil belajar yang ditekankan dalam penelitian ini adalah hasil belajar kognitif yang telah diklasifikasi oleh Bloom dengan revisi dari Anderson dan Krathwohl, yang meliputi mengingat, memahami, menerapkan, menganalisis, mengevaluasi, dan mencipta. Nuryani (2005) menjelaskan sub ranah kognitif dideskripsikan sebagai berikut: Mengingat (remember), Memahami (understand), Menerapkan (apply), Menganalisis (analyze), Mengevaluasi (evaluate), dan Mencipta (create).

Observasi yang dilakukan Dosen peneliti pada tanggal 9 dan 16 Februari 2017 di Kelas 4A P.IPA angkatan 2015, pada matakuliah Pendidikan Sains, Dosen peneliti menemui beberapa fakta mengenai kegiatan belajar mahasiswa. Mahasiswa melakukan diskusi presentasi mengenai teori belajar dimana ada satu kelompok yang bertugas sebagai penyaji, sedangkan sisanya menjadi audience. Pembelajaran yang berlangsung di ruang E1.2 ini terlihat kurang kondusif untuk kegiatan diskusi, mahasiswa duduk secara berbanjar dan berpencar-pencar.

Presentasi hanya disimak oleh mahasiswa di deretan depan, sedangkan sisanya melakukan kegiatan yang tidak ada hubungannya dengan matakuliah. Dari diskusi yang dosen peneliti amati, mahasiswa sudah mampu membuat tayangan power point yang menarik dengan materi yang mudah dipahami. Kemampuan kelompok penyaji dalam menyampaikan materi juga sudah cukup baik. Hanya saja disini mahasiswa audiens yang tidak bertugas untuk melakukan presentasi perlu untuk dikondisikan agar lebih aktif dan pembelajaran dapat berlangsung lebih bermakna.

Model pembelajaran yang akan digunakan pada penelitian ini adalah model pembelajaran simposium. Simposium adalah serangkaian pidato pendek di depan audiens 
dengan seorang pemimpin. Simposium menampilkan beberapa orang pembicara dan mereka mengemukakan aspek-aspek pandangan yang berbeda dalam topik yang sama.

Pembicara dalam simposium terdiri dari pembicara (pembahas utama) dan penyanggah (pembanding), dibawah pimpinan seorang moderator. Pendengar diberi kesempatan untuk mengajukan pertanyaan atau pendapat setelah pembahas utama dan penyanggah selesai berbicara. Moderator hanya mengkoordinasikan jalannya pembicaraan dan meneruskan pertanyaan-pertanyaan, sanggahan atau pandangan umum dari peserta. Hasil simposium dapat disebarluaskan, terutama dari pembahas utama dan penyanggah, sedangkan pandangan-pandangan umum yang dianggap perlu saja.

Pemilihan model pembelajaran ini untuk diaplikasikan dalam penelitian karena selain model pembelajaran ini jarang digunakan, model ini diperkirakan dapat meningkatkan keaktifan siswa, karena selama kegiatan siswa dituntut untuk aktif, kreatif, dan memiliki pendapat tersendiri yang dapat dibagikan di depan kelas. Model pembelajaran simposium juga diharapkan dapat meningkatkan minat siswa terhadap materi yang sedang diajarkan dan membuka wawasan yang lebih luas terhadap topik-topik tertentu yang sedang dikaji.

\section{METODE}

Penelitian ini merupakan penelitian kualitatif dengan menggunakan penelitian tindakan kelas (PTK) yang digunakan untuk memperoleh informasi dan gambaran tentang aktifitas dan hasil belajar mahasiswa selama proses pembelajaran.

Adapun pendekatan penelitian adalah penelitian deskriptif kualitatif. Pada penelitian ini menggunakan metode ilmiah dimana peneliti menyelidiki, memaparkan data secara alami berdasarkan data di lapangan. Di dalam penelitian ini peneliti bertindak sebagai pengumpul data dan penganalisis data juga terlibat dalam proses penelitian.

\section{Subjek Penelitian}

Subyek peneitian ini adalah mahasiswa PGSD kelas 4A semester IV tahun pelajaran 2016/2017 STKIP PGRI Tulungagung pada matakuliah Pendidikan Sains, dengan jumlah mahasiswa 38 orang yang terdiri dari 10 mahasiswa laki-laki dan 28 mahasiswa perempuan.

\section{Data, Instrumen Pengumpul Data, Sumber Data dan Proses Pengambilan Data}

Pengambilan data pada penelitian ini menggunakan 3 instrumen pengambilan data, yaitu lembar observasi monitoring PTK, lembar observasi Pemahaman belajar mahasiswa, 
lembar test hasil belajar dan catatan lapangan. Data, sumber data dan instrumen penelitian dalam penelitian ini dapat dilihat pada Tabel.3.1.

Lembar observasi Tingkat pemahaman Belajar mahasiswa dan observasi keterlaksanaan PTK diisi oleh observer digunakan untuk melihat peningkatan yang terjadi karena pelaksanaan Active Learning. Lembar observasi ini akan diisi oleh observer dalam pelaksanaan pembelajaran. Observer yang dipilih merupakan rekan dosen di Prodi P.IPA STKIP PGRI Tulungagung.

\begin{tabular}{|l|l|l|}
\hline \multicolumn{1}{|c|}{ Jenis Data } & \multicolumn{1}{|c|}{ Sumber Data } & \multicolumn{1}{c|}{ Instrumen } \\
\hline Tingkat pemahaman & Aktivitas mahasiswa & 1. Lembar observasi Tingkat pemahaman \\
Belajar siswa & & \multicolumn{1}{c}{ Belajar klasikal siswa } \\
& & 2. Lembar observasi keterlaksanaan PTK \\
hasil belajar kognitif & & 3. Catatan lapangan \\
& & 4. Lembar test hasil belajar \\
& & \\
\hline
\end{tabular}

Tabel 1. Matrik Jenis Data, Sumber Data dan Instrumen Penelitian

Penelitian ini akan dilaksanakan selama 2 siklus dimana setiap siklusnya terdiri dari rencana tindakan, pelaksanaan tindakan, observasi, dan refleksi. Siklus tindakan dalam penelitian ini terdiri dari dua siklus, setiap siklus tindakan secara umum mempunyai modelmodel penelitian yang memiliki alur yang sama. Analisis data dalam penelitian ini meliputi kegiatan mengelola data mentah, menyajikan data, menarik kesimpulan dan melakukan refleksi. Dalam penelitian ini data yang diperoleh berupa data pemahaman belajar mahasiswa. Selain itu juga diperoleh data pendukung tentang kegiatan Dosen dan catatan lapangan. Untuk mengetahui persentase keberhasilan aktivitas mahasiswa secara klasikal dapat dihitung dengan menggunakan rumus sebagai berikut.

Persentase keberhasilan tindakan = Jumlah mahasiswa yang melakukan indikator_x $100 \%$

\section{Jumlah total mahasiswa}

(Arikunto, 2001:236)

\section{HASIL DAN PEMBAHASAN}

Data yang diperoleh pada siklus I dan siklus II tampak bahwa pemahaman belajar mahasiswa mengalami peningkatan. Berdasarkan hasil tersebut, dapat dikatakan bahwa 
penerapan pembelajaran aktif dengan metode simposium dapat meningkatkan motivasi belajar mahasiswa. Data hasil belajar kognitif mahasiswa diperoleh dari hasil tes akhir siklus I dan tes akhir siklus II. Dari data yang telah di peroleh dan dianalisis diketahui bahwa rata-rata nilai siswa mengalami kenaikan yaitu dari 79.4 menjadi 81.5.

Aspek yang dibahas dalam bab ini adalah mengenai tingkat pemahaman dan hasil belajar mahasiswa dalam ranah kognitif selama perkuliahan yang dilaksanakan dengan Pembelajaran Aktif mengimplementasi model pembelajaran simposium pada matakuliah pendidikan sains materi faktor biotik dan prinsip ekologi.

Berdasarkan data hasil observasi awal didapatkan fakta bahwa aktivitas mahasiswa pada saat pembelajaran masih kurang karena mahasiswa masih banyak yang pasif dan yang aktif hanya beberapa mahasiswa di deretan bangku depan. Hal tersebut terjadi karena pada saat observasi awal, mahasiswa hanya melakukan presentasi biasa tanpa pengawasan dosen sehingga kegiatan menjadi monoton dan kurang hidup. Selain itu, mahasiswa juga banyak melakukan hal-hal yang kurang relevan dengan perkuliahan seperti mengerjakan tugas dari matakuliah lain, bermain gadget,mengobrol, tidur, dan lain sebagainya.

Selama proses pembelajaran berlangsung, peneliti dibantu oleh observer untuk mengamati dan menilai aktivitas mahasiswa pada saat proses pembelajaran. Berdasarkan pengamatan yang dilakukan oleh observer dan analisis data didapatkan hasil bahwa telah terjadi peningkatan pemahaman belajar mahasiswa.

Berdasarkan hasil dan analisis data yang telah didapatkan setelah tindakan dapat disimpulkan bahwa pembelajaran aktif dengan metode simposium mampu meningkatkan pemahaman dah hasil belajar kognitif mahasiswa yang ditunjukkan oleh peningkatan nilai tes mahasiswa dari siklus I ke siklus II.

Berdasarkan fakta yang ada pada hasil observasi dan pernyataan bahwa hasil belajar dipengaruhi oleh pengalaman subjek belajar dengan dunia fisik dan lingkungannya, maka peneliti melakukan sebuah penelitian.

Untuk hasil belajar pada ranah kognitif, Dosen peneliti mengukur kemampuan kognitif mahasiswa dengan menggunakan tes setelah pembelajaran setiap siklus tindakan dilakukan. Berdasarkan hasil dan analisis data yang telah didapatkan setelah tindakan dapat disimpulkan bahwa penerapan Lesson Study dalam pembelajaran aktif dengan metode simposium mampu meningkatkan hasil belajar mahasiswa dalam ranah kognitif. Keberhasilan tersebut ditunjukkan oleh peningkatan rata-rata hasil belajar kognitif mahasiswa setelah melakukan tes dari siklus I ke siklus II. Peningkatan hasil belajar kognitif ditunjukkan dengan peningkatan rata-rata hasil belajar kognitif secara klasikal yaitu sebesar 79.4 pada siklus 1 menjadi sebesar 81.5 pada siklus tindakan II. 
Dari penelitian yang telah dilaksanakan oleh Dosen pembimbing terbukti bahwa pembelajaran aktif menggunakan metode symposium dapat meningkatkan hasil belajar mahasiswa PGSD kelas 4A semester IV tahun pelajaran 2016/2017 STKIP PGRI Tulungagung pada matakuliah Pendidikan Sains materi faktor biotik dan prinsip ekologi.

\section{KESIMPULAN}

Berdasarkan Penelitian Tindakan Kelas yang telah dilakukan oleh dosen pembimbing matakuliah diperoleh kesimpulan bahwa Pembelajaran aktif dengan implementasi model pembelajaran simposium dapat meningkatkan pemahaman dan hasil belajar kognitif mahasiswa pada matakuliah pendidikan sains.

Hal ini dibuktikan dengan Hasil tes tiap akhir siklus yang mengalami peningkatan. Pada siklus 1 tindakan, rata-rata nilai tes mahasiswa adalah 79.4 dan pada siklus 2 tindakan meningkat menjadi 81.5. Pada pelaksanaan penelitian, dosen pembimbing sebaiknya melakukan observasi kelas dalam jangka waktu yang lebih lama sehingga semakin banyak permasalahan yang ditemui dan dapat dicari solusinya. Dosen pembimbing juga sebaiknya mengumpulkan lebih banyak literatur dan melakukan sharingsehingga segala perencanaan yang akan dilaksanakan di kelas lebih matang dan terstruktur dengan baik.

\section{DAFTAR PUSTAKA}

Alifi, 2007. Upaya peningkatan Motivasi dan Hasil Belajar Biologi Melalui penerapan Pembelajaran Kooperatif TAI pada Siswa kelas VIII E SMP Negeri 1 Gedeg Mojokerto. Skripsi tidak diterbitkan. Malang: FMIPA UM.

Dimyati \& Mudjiono. 2006. Belajar dan Pembelajaran. Jakarta: Rineka Cipta.

Gora, Winastwan \& Sunarto. 2010. Pakematik Strategi Pembelajaran Inovatif Berbasis TIK. Jakarta: IT. Bumi Aksara.

Hamalik, Oemar. 2001. Proses Belajar Mengajar. Jakarta: PT. Bumi Aksara.

Hollingsworth P., Lewis G. 2008. Pembelajaran Aktif. Jakarta: PT. Indeks.

Nasriadi. 2018. "Penerapan Metode Diskusi Simposium dalam Pembelajaran Sosiologi untuk Meningkatkan Motivasi Belajar Siswa Kelas X.B SMA Negeri 2 Baebunta Kab. Luwu Utara”. Journal Sociology of Education. Vol. VI. Issue 1. Januari-Juni 2018 E_ISSN: 23392401/P_ISSN: 2477-0221, diakses 30 April 2020

Peraturan Menteri Pendidikan Nasional Republik Indonesia Nomor 41 tahun 2007 tentang Standar Proses 
Rahayu, A.D.P. 2017. "Pengaruh Metode Simposium Yang Didukung Media Visual Fliptchart Untuk Meningkatkan Kemampuan Siswa Dalam Menceritakan Tokohtokoh Pada Masa Hindu- Budha Kelas V Sdn Sembon I Kecamatan Karangrejo Kabupaten Tulungagung Tahun Pelajaran 2016/2017”.

Skripsi tidak diterbitkan. Kediri: PGSD Universitas Nusantara PGRI Kediri.

Sardiman, A.M. 2003. Interaksi dan Motivasi Belajar Mengajar. Bandung: CV. Remadja.

Samadhi, T.M.A. Ari. 2008. Pembelajaran Aktif, Teaching Improvement Workshop, Engineering Education Development Project ADB Load No. 1432-INO

Sholeh, M.H. 2011. Metode Edutainment. Jogjakarta: Diva Press.

Silberman, M.L. 2006. Active Learning: 101 Strategi Pembelajaran Aktif. Yogyakarta: Pustaka Insan Madina.

Tafsir, Ahmad. 2011. Metodologi Pengajaran Agama Islam. Jakarta: Rosda Karya.

Widodo, A. 2008. Peningkatan Kemampuan Mengajar Guru-guru SD melalui Lesson Study.

(Online), (http:/jurnal.upi.edu/file/Jurnal_Aril.pdf), diakses 3 Februari 2017. 